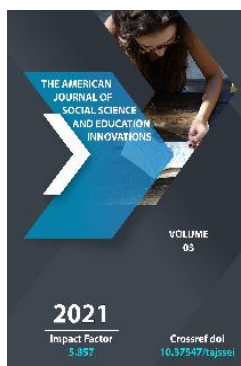

\title{
Lexical Features Of The Publicistic Style
}

\author{
Jumakulova Gulnoza Zamirovna \\ Teacher Of The English Language Teaching Methodology Department, Foreign Languages \\ Faculty, Fergana State University, Fergana, Republic Of Uzbekistan
}

Journal Website:

http://theamericanjour

nals.com/index.php/taj

ssei

Copyright: Original content from this work may be used under the terms of the creative commons attributes 4.0 licence.

\section{ABSTRACT}

The article under discussion reveals the issues of lexical features of publicistic style. The current study is an attempt to conduct a comprehensive study of the publicistic style taking into account the penetration of elements of other functional styles of modern English. The author of the article came to conclusion that the use of abstract vocabulary plays a major role in the publicistic style.

\section{KEYWORDS}

Publicistic style, features, lexical, elements, functional styles, system, independent, grammatical, borrowings, abbreviations.

\section{INTRODUCTION}

In the system of speech styles of modern English from about the middle of the XVIII century began to isolate a special style, which is called a publicistic style. Like other speech styles, it is not homogeneous [1, p.34]. A publicistic style is an independent functional style, which has a certain social purpose, a combination of linguistic functions, which has as its main purpose a message, an appeal and persuasion (impact). The mass media perform the following functions in society: information, informing the society about events and facts taking place in the society [3, p.66]. Therefore, the newspaper-publicist style has a wide range of linguistic, grammatical and compositional features that help to bring the author closer to the interlocutor. 
In linguistic terms, this style promptly registers the emergence of new words and expressions, borrowings and specific abbreviations accepted in the national language, abounds in internationalisms.

The use of elements of all functional styles and even non-literary forms of the English language, including jargonisms, is observed in the newspaper texts. At the same time, the colorfulness and expression of the publicistic style is due to the use:

- Speech standards, clichés ("employment service", "power departments")

- Typical newspaper phrases (to reach the advanced lines, beacons of production);

- Scientific terminology beyond the scope of highly specialized usage (virtual world, default, investment, mortgage, leukemia);

- Socially colored synonyms (gang of hired killers);

- Unusual lexical compatibility (whip preacher, apostle of ignorance);

- Words that reflect social and political processes in society (politics of dialogue, balance of interests);

- New words and expressions (détente, consensus, cold war);

- Social and political vocabulary and phraseology (society, freedom);

- Stylistically inferior words with a negative evaluation (pirate course, policy of aggression and provocation);

- Clerical language stamps influenced by the official business style (at this stage, as of today, in this period of time);

- Colloquial words and expressions (to bar, to ban, to ax, slang - to snog (to kiss), booze (alcohol)) [2, p.51].
Researchers have noted a large percentage of proper names: toponyms, anthroponyms, names of institutions and organizations, etc., a higher percentage of numerals and an abundance of dates compared to other styles. From the etymological point of view, there is an abundance of international words and a tendency to innovations, which, however, very quickly turn into clichés: vital issue, free world, pillar of society, escalation of war, terrible tension, plea of mercy, phraseological phrases: to give smb. the boot (to fire). The abundance of clichés has long been noticed and is pointed out by all researchers. All of these clichés, as well as some litotes like not unimportant, not unworthy, etc., give the text a profound sound, even if its content is completely trivial, for example: in my opinion it is not an unjustifiable assumption that instead of I think. Clichés serve situations that are regularly repeated within the newspaper style. Many clichés are drawn from professional jargon (polit. hard-liner conservative), many from general slang (thinktank brain).

The author of the article under discussion notes a large percentage of abstract words, although the information is, as a rule, concrete. There is an abundance of evaluative and expressive vocabulary rather than emotional: When the last Labour Government was kicked out. (Daily Mail). This evaluative nature is often evident in the choice of elevated vocabulary.

Finally, a feature of the publicistic style are allusions to well-known facts and events of the day. The most frequent allusions are found in articles commenting on the events of the internal life of the country. Depending on the nature of the newspaper, on the content of the article itself, on the purpose pursued by 
the author, the nature of the allusions, the type of imagery and the ratio of colloquial and bookish elements in the article change.

In the newspaper-publicistic style there is a vocabulary of professionalisms. The purpose is to facilitate the perception of information by the reader, to achieve a certain communicative impact. Political terms express precisely defined political concepts, such as republic, monarchy, national servanty.

Also worth noting is the replacement of a simple verb with a stable combination, which adds extra syllables to each sentence and creates the impression of greater fluidity: militate against, make contact with, be subjected to, have the effect of, play a leading part (role) in, take effect, exhibit a tendency to, serve the purpose of, etc. Such combinations most often involve such verbs as prove, render, serve, form, play. They are often used in the passive form: greatly to be desired, a development to be expected, brought to a satisfactory conclusion.

Compositional features include variability in the design of the title, the presentation of the main information and the main idea, usually at the beginning of the text $[6, p .188]$.

\section{CONCLUSION}

The relevance of studying the language of the publicistic style is due to the increasing importance of the periodical press, due to changing constantly socio-political conditions of life around the world and the need for information in everyday life.

The purpose of newspaper-publicistic texts is to influence, instill a certain kind of opinion, as well as interest in current events among readers. Through better orientation in the events covered by the newspapers, people's opinions, political views and attitudes are formed $[4$, p.125].

Thus, at the lexical level the publicistic style is characterized by neologisms, phraseology, colloquialisms, professionalisms an abundance of clichés and clichés. The need to compress information leads to the use of abbreviations.

\section{REFERENCES}

1. Dr. Margherita Dore. (2000). Introduction to Stylistics. Italy: Sapienza. P. 34.

2. Hasan Ghazala. (2011). Cognitive stylistics and the translator. Austarlia: Sayyab books. P. 51.

3. Jumakulova Gulnoza Zamirovna (2020). Linguistic peculiarities of publicistic style. Problemy sovremennoj nauki i obrazovanija, (6-2 (151)), 65-67. URL: https://cyberleninka.ru/article/n/linguis tic-peculiarities-of-publicistic-style.

4. Jumakulova Gulnoza Zamirovna (2019). Linguistic aspects of publicistic style in the global network. Проблемы современной науки и образования, (12-2 (145)), 124-126. URL: https://cyberleninka.ru/article/n/linguis tic-aspects-of-publicistic-style-in-theglobal-network.

5. Paul Simpson. Stylistics. (2004). A resource book for students. London and New York: Routledge. P. 262.

6. Stepanova I.V. (2012). Stylistics of the English language. Russia: Chelyabinsk state university. P.188. 